\title{
NEKE ODREDNICE RAZVOJA ZAJEDNICE I PROMOCIJE ZDRAVLJA OBITELJI, DJECE I MLADIH
}

Suvremeni pristupi određenju zdravlja opisuju ga kao stanje potpunog tjelesnog, duševnog i socijalnog blagostanja, a ne samo odsustva bolesti. Naročito osjetljive društvene skupine poput obitelji, djece i mladih, ali i brojne specifične kategorije stanovništva poput izbjeglica, siromašnih, etničkih, seksualnih ili rasnih manjinskih skupina pogođene su dodatno u zajednicama u kojima žive upravo putem utjecaja koji prema njima vrše članovi te iste zajednice. U radu su prikazane neke ključne odrednice koncepata razvoja zajednice i promocije zdravlja, obilježja konteksta u kojima se procesi razvoja zajednice i promocije zdravlja odvijaju, specifičnosti pojedinih modela rada, njihovih ključnih vrijednosnih odrednica i njihovi ciljevi.

\section{UVOD}

Pogled na zdravlje kao na stanje potpunog tjelesnog, duševnog i socijalnog blagostanja tijekom proteklih nekoliko desetljeća dobiva sve više potvrde u brojnim teorijskim, praktičnim i istraživačkim aktivnostima kako unutar medicinske profesije tako i izvan nje. O tome svjedoči i sve snažnija orijentacija prema proučavanju društvenih odrednica zdravlja. I dok je tijekom povijesti razumljivi naglasak stavljan na komponentu tjelesnog, razvojem društvenih 
znanosti i interdisciplinarnom suradnjom zdravlje postaje fenomen koji se istražuje sveobuhvatno. Čimbenici poput dostupnosti zdravstvenih usluga, socijalne podrške, zaposlenosti, socio-ekonomskog statusa ili stupnja marginalizacije članova zajednice uslijed spola, seksualne orijentacije, jezika, siromaštva i drugih odrednica postaju dio paradigme javnozdravstvenog pristupa razvoju i promociji zdravlja. U tome se osobiti naglasak stavlja na proučavanje uloge koju za zdravlje stanovništva ima zajednica shvaćena bilo kao teritorijalna zajednica ili kao interesna zajednica. Uloga zajednice istraživana je s mnogobrojnih aspekata i danas je neosporna važnost uključivanja koncepta razvoja zajednice u proces javnozdravstvenih intervencija, osobito u procese promocije zdravlja. Važnost zajednice u poboljšavanju zdravlja ističe i Svjetska zdravstvena organizacija kroz tzv. Inicijativu iz Verone (Bertinato, 2000). Njome se žele posebno istaknuti društvene i ekonomske odrednice zdravlja te se, među ostalim, navodi sljedeće:

1. postoji veoma dobro uspostavljena i uska veza između društvene i ekonomske okoline, javnih politika i zdravstvenih ishoda unutar zajednica

2. vidljive su rastuće nejednakosti u zdravlju koje se odražavaju u pristupu podržavajućoj okolini važnoj za zdravlje (pristup zdravoj hrani, rekreaciji itd.)

3. povećava se razina općeg psihosocijalnog stresa uslijed društvenih i kulturnih promjena

4. povećani konzumerizam i bolje razumijevanje „ovisnosti“ utjecali su na to da zdravstveni i socijalni sistemi diljem svijeta preorijentiraju svoje pristupe na način da postaju „partneri“, a ne samo „pružatelji usluga“ zajednici.

Posebno osjetljive društvene skupine, među kojima se ističu obitelj, djeca i mladi (ali i brojne druge) pod pojačanim su pritiskom uslijed slabljenja dostupnosti ne samo zdravstvenih nego i široko shvaćenih socijalnih usluga. Razlozi tome leže kako u ekonomskim okolnostima (sve veći pritisci na smanjenje „socijalnih izdataka“ zbog jačanja globalne kompetitivnosti nacionalnih ekonomija, negativnih demografskih trendova i drugih faktora) tako i u nedovoljno razvijenim modelima rada koji proizlaze iz neefikasno pripremljenih zdravstvenih i socijalnih sustava. Modeli razvoja zajednice i promocije zdravlja pružaju brojne mogućnosti za svojevrsnu rekonceptualizaciju onih sustava koji ih još nisu inkorporirali te za kontinuirano povećanje efikasnosti onih koji ove modele već poznaju, ali ih ne koriste u dovoljnoj mjeri ili na zadovoljavajući način. 


\section{ZAJEDNICA}

Proučavanje zajednice predmet je interesa brojnih autora tijekom desetljeća, pa i stoljeća. Ne ulazeći u povijesne aspekte razmatranja koncepta zajednice korisna se čini perspektiva koju nudi ekološka sistemska teorija (Bronfenbrenner, 1989). Sukladno ovoj teoriji zajednica predstavlja svojevrsni mikro sistem koji se sastoji od mreža odnosa čije je obilježje susret članova licem u lice. Veze i procesi koji se pojavljuju između dva ili više mikro sistema stvaraju mezo sistem. Mezo sistemi pojavljuju se u dva oblika. Prvi se sastoji od direktnih odnosa u kojima su obilježja jednog ili više mikro sistema povezana s obilježjima drugog mikro sistema, a ti odnosi uključuju pozitivna i negativna preklapanja i nadopunjavanja. Drugi tip mezo sistema sastoji se od kombiniranih utjecaja dva ili više mikro sistema na individualnoj, obiteljskoj i razini zajednice. Te veze stvaraju sučelje koje može imati tri oblika: 1. nezavisno i dodatno, 2. medijacijsko ili 3. interaktivno.

Pokušaji definiranja zajednice uglavnom su slijedili kriterij empiričnosti i kriterij normativnosti. U deskriptivnom smislu distinkcija se može povući između zajednice u smislu lokalnosti, i zajednice u smislu njezinih obilježja ili interesa. U povijesnom smislu predindustrijske zajednice u kojima ljudi žive bile su male po prostoru, često ruralne, a ljudima su davale jednake mogućnosti za stvaranje socijalnih interakcija. Urbani razvoj i industrijalizacija počeli su mijenjati okolnosti u kojima ljudi žive i zajednica počinje sve više predstavljati "zlatno doba" koje je neminovno prošlo. Studije zajednice odnosno života u zajednici zaokupljaju sve veću pažnju istraživača tijekom 50ih i 60ih godina 20. stoljeća. Takve studije bile su primarno locirane u zajednicama radničke klase, a među autorima najpoznatiji su Townsend, Wilmott i Young (prema Barnes, 1997).

U procesu organiziranja zajednice zajednici se pristupa kao izvoru vodstva i kolektivne snage zainteresiranih ljudi. Urbani sociolozi u svojim definicijama često povezuju prostor i asocijativne faktore npr. kontekst i socijalne odnose. Definicije koje razmatraju ulogu ljudskog faktora u zajednici istu definiraju kao "skupinu ljudi koji su socijalno međuovisni" i "koji dijele zajednička iskustva" ili kao "sinergičnu asocijaciju između institucionalnog konteksta" u životu njezinih članova (Gardner, 1991).

Koncept zajednice, kako smatra Gardner (1991) ima mnoga obilježja među kojima spominje:

- cjelovitost koja uključuje razlike

- zajedničke vrijednosti

- skrb, povjerenje i timski rad

- uspješnu internu komunikaciju 
- participaciju

- afirmaciju

- veze izvan zajednice

- razvoj mladih ljudi

- sustav institucija za podršku zajednice

Zajednice mogu imati, ali i ne moraju dovoljno resursa da zadovolje materijalne i ine pretpostavke za razvoj svojih članova. Zajednice se bitno razlikuju u tome koliko su njeni stanovnici spremni se angažirati u različite oblike zajedničkih aktivnosti.

U području socijalnih i zdravstvenih službi izraz zajednica ima svoje osobito značenje. U tom kontekstu izraz zajednica može upućivati na različite ustanove, neprofitne organizacije ili agencije i njihove mreže, a može se odnositi na dominantnu orijentaciju koju ove službe imaju u pružanju svojih usluga. Iz svega toga proizlazi da je veoma važno napomenuti o kojoj se zajednici govori kad se koristi taj izraz i što se u danom slučaju podrazumijeva pod pojmom zajednica.

\section{ZAJEDNICA I ZDRAVLJE}

Zajednica i koncept zdravlja nerazdvojivo su povezani. Zdravlje u zajednici može omogućiti zajednici da stvori i uspješno koristi resurse s ciljem podrške dobrobiti i kvalitete života zajednice. U tome je važno da se zajednica suoči s izazovima i zaprekama koje se pojavljuju u okolini. Zdravlje u zajednici uključuje recipročne odnose između ljudi i njihove okoline s ciljem postizanja održivosti (Ryan-Nicholls \& Racher, 2004). Proenca (1998) koristi termin „orijentacije na zajednicu“ koji se odnosi na skup aktivnosti koje zdravstvene organizacije moraju oblikovati u suradnji s drugim institucijama kako bi upravljale zdravljem u zajednici. Seay and Sigmond (1989) govore o „pokretu zdravlja u zajednici“ te smatraju da su obilježja zdravstvenih ustanova koje su usmjerene na zajednicu vidljiva u: određenju njihove misije u kojem se ističe orijentacija na zajednicu, stavljanju na raspolaganje svojih resursa dobrobiti zajednice, procjenama zdravstvenog statusa zajednice, korištenju rezultata procjene za oblikovanje i modificiranje zdravstvenih usluga te u dugoročnom planiranju poboljšanja zdravlja zajednice. Zdravlje u zajednici moguće je postići jedino uspješnom i planiranom suradnjom različitih sektora koji u toj zajednici postoje i djeluju. Zajednica se sastoji od različitih dijelova koje možemo promatrati kao potencijalne suradnike i dionike procesa stvaranja zdravlja. Suradnja treba obuhvatiti poslovni sektor, obrazovanje, socijalne službe, javnu upravu, religijske zajednice, civilno društvo i druge. Kvalitetna međusektorska komunikacija koja uključuje pregovaranje, zagovara- 
nje, lobiranje i planiranje temelj je za uspješnu dugoročnu suradnju dionika iz različitih sektora. Prednosti intervencija u zajednici prije svega nalaze se u tome što one uzimaju u obzir društvene i okolinske uvjete koji doprinose zdravstvenim potrebama i problemima stanovništva, što su usmjerene svim skupinama stanovništva te uključuju principe primarne i sekundarne prevencije. Za zajednicu je od iznimne važnosti sudjelovanje njezinih članova u zajedničkim poslovima i događajima zajedničkog življenja. U tom slučaju možemo govoriti o aktivnim zajednicama koje neki autori nazivaju i „kompetentnim“ (npr. Cottrell, 1976) za razliku od onih entiteta koji postoje tek kao latentni dionici procesa izgradnje zdravlja. Brojne provedene empirijske studije koje su istraživale organizacijske i okolinske odrednice zdravlja u pravilu pokazuju iznimnu važnost zajednice u svim aspektima zdravlja članova zajednice. Među poznatijim istraživanjima mogu se istaknuti istraživanje Američke udruge bolnica (2000), istraživanje koje su proveli Olden i Clement (2000) ili istraživanje koje su proveli Proenca, Rosko i Zinn (2003). U svim ovim, kao i brojnim drugim istraživanjima, jasne su koristi koje po zdravlje stanovništva ima usmjerenost na zajednicu i općenito društvene odrednice zdravlja kao i na promociju zdravlja u zajednici. Među brojnim razvijenim modelima zdravlja u zajednici mogu se kao dobri primjeri istaknuti model Centra za promociju zdravlja pod nazivom „Model za kvalitetu života“ (Renwick i Brown, 1996), revidirani model „Elastičnosti zajednice“ (Kulig, 2000), Neuman-ov „Sistemski model“ (Neuman, 1995) ili model „Zajednica kao partner“ (Anderson i McFarlane, 2004). Brojne nove generacije intervencija u zajednici nadovezuju se i na dobro poznate koncepte koje su razvili Rothman i Tropman (1987) pod nazivom model lokalnog razvoja, socijalnog planiranja i socijalne akcije. Unutar ovih modela razmatraju se neki od ključnih koncepata zdravlja u zajednici kao što su koncept vodstva, rješavanja problema, sudjelovanja i razvoja zajednice.

\section{ZDRAVLJE I RAZVOJ ZAJEDNICE}

Razvoj zajednice predstavlja koncept koji se počinje razvijati osobito nakon završetka 2. Svjetskog rata kao posljedica procesa "dekolonizacije“ odnosno nastojanja da se bivšim (osobito britanskim) kolonijama u Africi omogući veći utjecaj u oblikovanju vlastitog razvoja. U međuvremenu koncept razvoja zajednice uvelike je nadrastao prvotni okvir i danas se koristi za najrazličitije procese usmjerene stvaranju uvjeta za ekonomski i socijalni napredak zajednice, a koji uključuje aktivno sudjelovanje i najšire moguće oslanjanje na inicijative u zajednici. Usmjerenost na zajednicu i njezin razvoj tijekom posljednjih nekoliko desetljeća značio je pomak u naglasku s individualne razine tretiranja zdravlja i ponašanja pojedinca prema utjecajima koje na zdravlje ima okolina. $U$ tome se 
razvoj zajednice snažno naslanja na ekološke modele prema kojima se smatra da je ponašanje pojedinca pod utjecajem dinamičke interakcije s društvenom okolinom koja uključuje utjecaje na interpersonalnoj i organizacijskoj razini, razini zajednice te na političkoj razini. (Merzel i D’Afflitti, 2003).

Mason i sur. (2008) ističu da se tijekom posljednjih 30 godina pojavila nova paradigma u zdravstvenoj skrbi. Ta paradigma zasniva se na aktivnom sudjelovanju zajednice koja nastoji pomaknuti naglasak sa skupe medicinske skrbi. Prema mišljenju Kar-a i sur. (1999) unutar javnog zdravstva postoje tri glavna obilježja „osnaživanja zajednice“ koja se razlikuju od tradicionalnog medicinskog modela. Prvo to je obilježje koje naglasak stavlja na preveniranje bolesti i promociju pozitivnog zdravlja, a ne tretira samo bolest. Drugo, jedinica intervencije je zajednica više nego što je to pojedinac. I na koncu treće, promiče se strategija koja povezuje i potiče šire bihevioralne, društvene i okolinske promjene koje su nužne za promociju zdravlja.

Baisch (2009) ističe da su zdravstvene inicijative utemeljene u zajednici sve češće od 80ih godina prošlog stoljeća te da se istraživanja o tom fenomenu počinju pojavljivati sve češće u području sestrinstva, javnog zdravstva te u sociološkoj literaturi.

Među brojnim određenjima razvoja zajednice možemo navesti ono koje smatra da razvoj zajednice predstavlja „proces njegovanja osjećaja zajednice, jačanja socijalnih veza među ljudima, podizanja kohezije s ciljem postizanja harmonične, podržavajuće, i za život poticajne i zanimljive okoline ljudima" (Rootman i Raeburn, 1994). Proces razvoja zajednice za zdravlje usmjeren je omogućavanju aktivnog uključivanja ljudi, osobito onih koji su najviše zapostavljeni i marginalizirani u smislu donošenja odluka i organizacija koje utječu na njihovo zdravlje i život općenito. Proces razvoja zajednice odvija se na različitim razinama, a uključuje omogućavanje ljudima da zajednički djeluju i razmjenjuju iskustva, znanja i vještine, da podignu razinu svojeg sudjelovanja te da ih se ohrabri u uključivanju u kreiranje politike i procese pružanja usluga. Pored naziva "razvoj zajednice“ u upotrebi se mogu pronaći i drugi srodni nazivi poput „izgradnje zajednice“, „izgradnje kapaciteta zajednice“, „organiziranje zajednice“ itd. Labonte i Laverack, (2001) proces izgradnje kapaciteta zajednice opisuju kao podizanje sposobnosti (vještina, resursa i socijalnih mreža) grupa u zajednici da utvrde probleme u zajednici i utječu na njih. Pri tome je osobit naglasak stavljen na strategije koje se odvijaju po principu od dolje prema gore tj. s niže razine prema višoj nastojeći time da se fokus stavi na aktivnost članova zajednice kao na proces, a ne samo na probleme i deficite u zajednici. Proces razvoja zajednice zasniva se na razvoju resursa u zajednici koji se mogu između ostalog pronaći u grupama za samopo- 
moć, sustavu socijalne podrške ili razvoju sustava koji jačaju sudjelovanje građana u usmjeravanju i oblikovanju zdravstvenih prioriteta. Sudjelovanje građana osobito je važna karika ukupne politike zdravlja i to zbog različitih razloga. Tako npr. South i sur. (2009) navode da su ljudi posvećeni svojim zajednicama i žele im nešto zauzvrat dati; ljudi se poznaju u zajednicama u kojima žive i osjećaju povjerenje te znaju kako drugi članovi zajednice žive; obični ljudi imaju potencijal da utječu na svoje zajednice koje profesionalci nemaju, mogu prezentirati informacije i ponuditi odgovarajuću podršku budući da poznaju lokalne kulture i običaje. Nadalje, uključivanje članova zajednice je dobar način da programi dopru do ljudi kojima zaista trebaju, stanovnici zajednice imaju više povjerenja u ljude koje poznaju nego u nepoznate stručnjake; stručnjaci mogu naučiti različite stvari radeći s članovima zajednice; ljudi mogu puno dobiti sudjelovanjem u poslovima zajednice uključujući veći stupanj osobnog povjerenja i samopoštovanja te sudjelovanje u stvaranju pozitivne promjene u zajednici može biti poticajno i može predstavljati užitak članovima zajednice. Povrh toga sudjelovanje može predstavljati mogućnost za učenje novih vještina, a može predstavljati i dobru priliku za pronalaženje radnog mjesta; uključivanje članova zajednice može dugoročno donijeti bolje zdravlje kroz prihvaćanje zdravih stilova života, osiguravanje dostupnosti socijalnih mreža i stjecanjem prilika za zapošljavanje i na koncu sudjelovanje članova zajednice ima smisla i zbog financijskih razloga iako ono nije potpuno besplatno, a ponekad ni jeftino.

Uključenost zajednice $u$ aktivnosti povezane sa zdravljem može se kretati od jednostavnog informiranja članova zajednice do situacije u kojoj zajednica ima ovlasti kontrole poslova vezanih uz zdravstvenu skrb. Stjecanje veće mogućnosti utjecanja na odlučivanje u vezi politike zdravlja povezano je s količinom moći koju članovi zajednice imaju. S tim u vezi proces razvoja zajednice snažno se oslanja na koncept osnaživanja koji se može definirati kao „proces putem kojeg se pojedincima i zajednicama omogućava stjecanje moći i uspješnog djelovanja s ciljem transformiranja njihovog života i njihove okoline" (Robertson i Minkler, 1994). Pri tome članovi zajednice mogu stjecati moć na način da se od njih traži mišljenje, konzultacije, da značajno sudjeluju u različitim fazama planiranja, donošenja i provedbe odluka (Chambers, 2001).

Razvoj zajednice i općenito koncept zdravlja u zajednici snažno se povezuje s konceptom socijalne pravednosti (Couto, 2000; Rafael, 2000; Awofeso, 2003; Turnock, 2001). Socijalna pravednost je često podređena konceptu globalne ekonomije što rezultira široko rasprostranjenim nejednakostima i nemogućnostima vlada da osiguraju dovoljno dostupnih resursa za razvoj zajednice i podizanje razine zdravlja. 
Za razumijevanje procesa razvoja zajednice osobito su važni koncepti civilnog društva i socijalnih mreža te s njima povezani koncept socijalnog kapitala. Civilno društvo je onaj skup nevladinih institucija koji je dovoljno snažan da predstavlja protutežu državi te da, iako ne sprječava državu u ispunjavanju svoje uloge čuvara mira i arbitra među glavnim interesima, ipak može bez obzira na to spriječiti je od dominiranja i atomiziranja ostatka društva. (Gellner, 1994). U središtu civilnog društva nisu organizacije nego građani koji prema Dahrendorfu (1997) trebaju kako privrženost tako i mogućnost izbora da u potpunosti realiziraju svoje životne sposobnosti. Ta privrženost zahtjeva varijacije autonomnih koalicija koje nazivamo civilno društvo. U širem smislu civilno društvo predstavlja sve one organizacije ili pokrete koji djeluju u području između obitelji, privatnog sektora i države i bave se stvarima od javnog interesa. Civilno društvo uključuje nevladine organizacije, skupine u zajednici, sindikate, obrazovne institucije i vjerske organizacije. Ono igra važnu i nezamjenjivu ulogu u pluralnom društvu. Omogućava (političku) moć pojedincima koji imaju zajedničke vrijednosti, probleme ili područja interesa. Zalažu se za to da se njihov glas čuje i nastoje utjecati na događaje u društvu. Uključujući se u organizacije civilnog društva ili u različite oblike neformalnih odnosa članovi zajednice stvaraju socijalne mreže, a upravo njihova gustoća, čvrstoća i snaga utjecaja čini socijalni kapital zajednice. Kako ističe Putnam (1993. i 1995.) socijalni kapital se sastoji od mreža i normi koje akterima omogućuju djelotvorno zajedničko djelovanje s ciljem ostvarenja zajedničkih ciljeva. Što se više ljudi međusobno povezuje, to će veće biti njihovo međusobno povjerenje odnosno to će bolja biti njihova pojedinačna i kolektivna pozicija i to stoga što socijalni kapital u sebi sadržava jaku kolektivnu komponentu. Prema Putnamu, „pokazatelji“ socijalnog kapitala uključuju izlaznost glasača, novinsko čitateljstvo, sudjelovanje u dobrovoljnim udruženjima, nazočnost na okupljanjima u zajednici, religijsku pripadnost, političke klubove, radničke sindikate, diskusijske i studijske te sportske klubove i organizacije. Po mišljenju Briggs-a (1997) socijalni kapital može imati funkciju poluge i podrške u društvu. Socijalni kapital kao poluga jest sposobnost navođenja drugih ljudi da pomognu riješiti probleme odnosno da „se krene naprijed“ dok socijalni kapital kao socijalna potpora znači oslanjanje na druge da pomognu ljudima da se „snađu“ ili jednostavno nose sa životnim izazovima. Koncepti civilnog društva, socijalnih mreža i socijalnog kapitala neizostavni su čimbenici koji doprinose razumijevanju i razvoju koncepta razvoja zajednice i zdravlja u zajednici.

Sumirajući, može se reći da je koncept razvoja zajednice i općenito zdravlja u zajednici utemeljen na filozofskom vjerovanju o socijalnoj pravednosti i osnaživanju. Kako smatra Baisch (2009) zdravlje zajednice postiže se putem sudjelu- 
jućeg procesa razvoja zajednice koji se temelji na ekološkim modelima, a koji se bave širokim odrednicama zdravlja. Stručnjaci različitih relevantnih disciplina koji su povezani sa zajednicom utječu na inicijative usmjerene poboljšanju zdravlja zajednice u partnerstvu sa članovima zajednice. Pri tome je fokus njihove suradnje prevencija bolesti i promocija zdravlja.

\section{PROMOCIJA ZDRAVLJA U ZAJEDNICI}

Koncept promocije zdravlja se aktualizira sredinom 80ih godina dvadesetog stoljeća i često se poistovjećuje s konceptom javnog zdravstva i zdravstva u zajednici (WHO, 1986). Ridde (2007) ističe da javno zdravstvo, zdravlje u zajednici i promocija zdravlja dijele zajedničke ciljeve i to: poboljšavanje zdravstvenog statusa ljudi kao skupina, a ne kao pojedinaca. Odnos između ova tri koncepta prikazan je u sljedećoj tablici 1:

Tablica 1. Odnos koncepata pristupu zdravlja

\begin{tabular}{|l|l|l|l|}
\hline & Proces & \multicolumn{2}{|c|}{ Krajnji cilj } \\
\cline { 1 - 2 } Javno zdravstvo & Tehnokratski & \multirow{2}{*}{ Poboljšavanje zdravlja stanovništva } \\
\hline Zdravlje u zajednici & Participativni & & $\begin{array}{l}\text { Smanjivanje društvenih } \\
\text { nejednakosti u zdravlju }\end{array}$ \\
\hline Promocija zdravlja & Osnaživanje & &
\end{tabular}

Razlozi sve veće orijentacije prema promociji zdravlja u zajednici mogu se naći u dva osnovna faktora: prvo, sve se više uviđalo da prebacivanje odgovornosti za loše zdravlje na pojedince podržava mentalitet okrivljavanja žrtve koji previđa strukturne odrednice zdravlja (Lalonde, 1974; Black, 1980; Tones, 1986) i drugo promotori zdravlja počeli su prepoznavati snage koje su daleko izvan kontrole pojedinaca, uključujući društvene norme i socioekonomski status (Goodman et al. 1996). Ovaj ideološki pomak razvijen u konceptu „novog javnog zdravstva" oblikovao je zajednice kao dio proizvodnje zdrave okoline (Awofeso, 2004; Beaglehole et al. 2004).

Kako se ističe u povelji iz Otawe (1986) „promocija zdravlja usmjerena je postizanju jednakosti u zdravlju. Akcije promocije zdravlja teže smanjivanju razlika u trenutnom zdravstvenom statusu“. Za koncept „novog javnog zdravstva“ (zacrtanog još na konferenciji u Alma Ati 1978. godine) Tulchinski i Varavikova (2010) ističu da „nije toliko koncept koliko je filozofija koja nastoji proširiti staro shvaćanje javnog zdravlja na način da uključuje razmatranje zdravlja pojedinca kao nastavka zdravlja populacije te na način da tematizira suvremena zdravstvena pitanja koja se bave jednakošću u dostupnosti zdravstvenim uslugama, oko- 
linom, političkim upravljanjem te socijalnim i ekonomskim uvjetima. Zdravlje se nastoji staviti u razvojni okvir kako bi se osigurala njegova zaštita od strane javne politike. Iznad svega novo javno zdravstvo se odnosi na akcije. Bavi se pronalaženjem i otvaranjem brojnih gorućih pitanja i problema te utvrđivanjem primjenjivih strategija s ciljem njihovog rješavanja".

Tulchinski i Varavikova (2010) ističu da je novo javno zdravstvo novo u tome što povezuje promociju zdravlja s dostupnošću zdravstvene skrbi; da ono predstavlja integraciju transdisciplinarnog i multiorganizacijskog djelovanja te da je osobito važno za sve zemlje, a osobito one s lošom infrastrukturom u primarnoj skrbi te u tranzicijskim zemljama. Isti autori smatraju kako se može uočiti rastući trend $\mathrm{u}$ korištenju promocije zdravlja kako bi se raspravila pitanja u kojima stil života i socijalni uvjeti predstavljaju glavne rizične faktore.

Merzel i Afliti (2003) ističu da promocija zdravlja u zajednici predstavlja konceptualni okvir koji naglašava primarnu prevenciju i perspektivu utemeljenu na suradnji sa stanovništvom. Programi utemeljeni u zajednici koriste multiple intervencije usmjerene na promjene na razini pojedinaca, grupa i organizacija te često uključuju strategije kreiranja politike i mijenjanja okoline kao što su mobiliziranje zajednice, aktivno sudjelovanje u provedbi programa, programe samopomoći, korištenje medija i tome slično.

Na promociju zdravlja može se gledati kao na filozofiju, proces, projekt ili ishod. Kao filozofija razvoj zajednice i promocija zdravlja u zajednici sadrže fundamentalno vjerovanje da ljudi mogu identificirati i rješavati svoje probleme. Kao proces promocija zdravlja u zajednici podržava građane da steknu moć utjecaja na promjene. Kao projekt ili ishod promocija zdravlja u zajednici odnosi se na postignute promjene u njihovim zajednicama (Racher i Anis, 2008).

Promocija zdravlja zasniva se na načelima koji uvažavaju perspektivu ljudskih prava, uključenosti, kvalitete i stalnog mjerenja učinaka. Kako navode Rootman i Raeburn (1994) glavna načela mogu se označiti kao: usmjerenost na ljude (njihovo svakodnevno iskustvo, perspektivu zajednice, posredničku ulogu stručnjaka), osnaživanje (kontrola od strane zajednice, skupina i pojedinaca u zajednici, pristup utemeljen na snagama i resursima zajednice), organizacijski razvoj i razvoj zajednice, sudjelovanje (što je moguće više ljudi, predstavništvo, popularne aktivnosti koje motiviraju, zadovoljavanje potreba i ojačavanje, zajedništvo predstavlja snagu i zdravlje), kvaliteta života (krajnji cilj promocije zdravlja, pozitivnost, duhovnost i duhovno zdravlje), evaluacija (djeluje li to?, procesne informacije, kibernetika i samokritika, odgovornost i vlasništvo, snaga podataka).

Prednosti intervencija u zajednici Sorensen et al. (1998) vide u tome što se one bave socijalnim i ekonomskim uvjetima koji doprinose kroničnim zdravstve- 
nim problemima, ciljaju različite grupe ljudi u zajednici, obuhvaćaju principe primarne i sekundarne prevencije te doprinose prevenciji širenja rizika. Izvedbena strana procesa promocije zdravlja u zajednici obuhvaća brojne ciljane aktivnosti koje se mogu opisati kao: sudjelovanje zajednice i mobiliziranje resursa, razvoj lokalnog vodstva, jačanje veza među organizacijama, stvaranje odnosa jednakosti s vanjskim dionicima, podizanje razine kontrole zajednice nad procesima upravljanja aktivnosti koje se odnose na promociju zdravlja, izgradnja infrastrukture za aktivnosti promocije zdravlja, osiguravanje održivosti procesa te izgradnja kapaciteta za rješavanje problema. O tome u svojim radovima, među ostalima, pišu i ovi autori: Kahn, 1982; Minkler \& Wallerstein. 1997; Hawe et al., 1999; Labonte \& Laverack, 2001; Butterfoss \& Kegler, 2002; Norton et al., 2002.

\section{IZVORIŠNE IDEJE I RAZVOJ RADA U ZAJEDNICI}

Tradicije prakse u zajednici ukorijenjene su u engleskom i američkom Settlement pokretu, pokretu Charity Organization Society, pokretu ruralnog razvoja, teorijama demokratske participacije te povijesti organiziranja i razvoja različitih etničkih i rasnih grupa (Betten i Austin, 1990.; Carleton-LaNey, 2001.; Rivera i Erlich, 1998.; Rubin i Rubin, 2001.; Weil \& Gamble, 2002.).

Murray Ross (1955., 1958.), kanadski znanstvenik iz područja rada u zajednici, bio je jedan od prvih znanstvenika koji je formulirao različite pristupe socijalnog rada u praksi usmjerenoj na zajednicu. Svoj rad temeljio je na teoriji društvene znanosti i formulirao principe prakse rada sa zajednicama. Njegova prezentacija principa ili modela donijela je jasnoću usmjerenja i definirala ciljeve prakse rada u zajednici. Diferencijacija u pristupima pruža korisnu uputu za stručnjake u odabiru metoda planiranja, organiziranja i akcije. Ross (1958) navodi kako „postoje brojni ciljevi i sukladno tome brojni pristupi koji su korisni kod rada u zajednici. Jednom kad smo odlučili što pokušavamo postići možemo odlučiti koji je pristup odgovarajući te koje metode su podudarne s krajem kojeg imamo u mislima".

Ross raspravlja o varijacijama u filozofijama i ocrtava vrijednosti i metode koje će usmjeriti odabir ciljeva. On opisuje „reformsku orijentaciju“ koja obuhvaća kako socijalnu akciju tako i napore na području političke prakse. Njegova „planska orijentacija“ razlikuje a) „istraživanje s ljudima“ koje promiče planiranje na najnižoj razini kao glavnu odgovornost stručnjaka u zajednici te b) „tehničku studiju o socijalnim potrebama“ koja „ohrabruje uravnotežene socijalne programe" a ona je poduzeta od socijalnog vijeća ili drugih tijela planiranja (Ross, 1958). Ross-ova „procesna orijentacija“ srodna je pristupima organiziranju zajednice i 
razvoju zajednice u kojima su članovi zajednice jasni vođe i oni koji postavljaju smjernice za rad na području jačanja veza u zajednici i organiziranja s ciljem poboljšavanja uvjeta u zajednici. Ta procesna orijentacija je vodilja za većinu organiziranja teritorijalnih ili funkcionalnih zajednica i jasno je povezana s kasnijim koncepcijama popularnog obrazovanja i strategija osnaživanja zajednice (Ross, 1958). Ross donosi zanimljive i još uvijek primjenjive primjere međunarodnog rada na razvoju kao i organizacija u kvartovima (1955., 1958.).

Mnogi praktičari na makro razini temelje svoj rad na tri glavna pristupa intervencija u zajednici koje je kao modele uveo Jack Rothman 1968. godine. Rothman (2001) je opsežno revidirao svoj originalni okvir lokalnog razvoja, socijalnog planiranja i socijalne akcije kako bi pružio složeniji, isprepleten pogled mješovitih i faznih načina intervencije u zajednici. Rothmanovi (1968) originalni modeli pružili su korisnu uputu za nove praktičare u zajednici, koji su se pojavili iz škola za socijalni rad tijekom 1960ih i 1970ih, u njihovom radu na području snažnog rasta neprofitnog sektora i programa protiv siromaštva, brojnih aktivnosti na području socijalnog planiranja te političke i socijalne akcije.

\section{RAZLIČITI MODELI RADA U ZAJEDNICI}

Taylor i Roberts (1985) elaborirali su pet modela rada u zajednici. Modeli: razvoj i koordinacija programa, planiranje, stvaranje veza u zajednici, razvoj zajednice te političko osnaživanje odgovorili su na neke od promjena koje su se pojavile u obrazovanju za praksu socijalnog rada tijekom ranih 1980ih budući da je profesionalno obrazovanje skrenulo više u smjeru socijalne administracije i bilo je manje uključeno u organiziranje na najnižim razinama (Patti, 1983.; Slavin, 1985.). Netting, Kettner i McMurty (2004.) polazeći od ranije konceptualizacije Kramera (1966.) razvili su širi okvir povezan s makro praksom koja obuhvaća kako praksu u zajednici tako i socijalnu administraciju te je definiran kao „profesionalno usmjerena intervencija oblikovana da postigne planiranu promjenu u organizacijama i zajednicama“.

Kasnija razrada na osam modela prakse u zajednici pokazala je kako je moguće široko identificirati intervencije prakse u zajednici u prvom desetljeću 21. stoljeća (Weil i Gamble, 2002.). Ti su se modeli pojavili u praksi i literaturi tijekom zadnjih pola stoljeća u radovima autora poput: (Ross, 1955, 1958; Harper i Dunham, 1959.; Rothman, 1968., 2001.; Ecklein i Lauffer, 1972; Brager i Specht, 1973.; Taylor i Roberts, 1985.; Rubin, 2000.; Rubin i Rubin, 2001.;; Weil i Gamble, 2002.; Homan, 2004.; Netting i sur., 2004). Ovi su modeli predstavljali test vremena kao korisni pristupi za pozitivnu socijalnu promjenu. Dodatno, ovi modeli 
mogu biti međusobno osnažujući kad su kombinirani ili korišteni u fazama - npr. kad grupa u zajednici pokrene aktivnosti na planu ekonomskog razvoja ili kad funkcionalna zajednica razvija usluge za stigmatiziranu ili zapostavljenu grupu (Weil, 1997.; Weil i Gamble, 2002.). Modeli rada u zajednici koji se osobito razmatraju su nazvani:

- organiziranje susjedstva i zajednice

- organiziranje funkcionalnih zajednica

- politička i socijalna akcija

- socijalni i ekonomski razvoj zajednice

- socijalno planiranje

- razvoj programa i veza u zajednici

- koalicije

- socijalni pokreti

Ovi se modeli mogu najbolje iskoristiti u svijetlu tri promjenjiva konteksta koja obilježavaju okolinu u kojoj ljudi žive u novom stoljeću i koji utječu na svaku praksu u odnosu na socijalne, ekonomske i političke promjene. Osam modela treba sagledati u kontekstu velikih promjena koje se događaju na globalnoj razini, a odnose se na: a) povećani broj multikulturalnih društava diljem svijeta, b) ekspanziju prava žena te daljnju ekspanziju ljudskih prava i c) globalizaciju te velike ekonomske, političke i socijalne promjene koje se pojavljuju diljem svijeta i stvaraju komplekse interaktivne utjecaje.

\subsection{Multikulturalni kontekst}

Sve više suvremenih društava postaje multikulturalno. Sukladno tome potrebne su političke, socijalne i ekonomske politike koje će donijeti napredniji i realističniji pogled na tu stvarnost. Diljem svijeta komunikacija i trgovina probile su granice na pozitivne, ali i na problematične načine. Primjerice djeca i mladi iz nerazvijenih dijelova svijeta imaju mogućnost pristupa internetu i otvaranju novih, ponekad prikrivenih mogućnosti za međunarodno povezivanje i informiranje dok u nekim područjima ekonomska moć multinacionalnih korporacija umanjuje nacionalne perspektive za razvoj. Samo u Africi trenutno ima više od 15 milijuna izbjeglica zbog rata, gladovanja i političkog nasilja. Izbjeglički pokret diljem svijeta veći je nego je ikad bio. Takva stvarnost povećava se i sa imigrantima iz južne polutke prema SAD-u i zapadnoj Europi u nadi da će pronaći posao i slobodu. U svim intervencijama u zajednici treba kritički razmotriti kulturalne i multikulturalne strategije (ili njihov nedostatak). Korištenje multikulturalne perspektive 
znači povlačenje od tradicionalno uskog fokusa na specifičnu kulturu prema korištenju širokokutnog pogleda višestrukih kulturalnih, rasnih i ekonomskih grupa u nekom geografskom području ili funkcionalnoj zajednici, nadalje analiziranje podudarnosti i razlika u interesima i perspektivama među tim grupama te između tih grupa i elita moći. S rastavljanjem sigurnosne mreže države, što je obilježilo zapadnu državu blagostanja, ekonomski status siromašnih različitog etničkog porijekla se pogoršao. To je povećalo siromaštvo te su se povećali utjecaji globalizacije na radnike s niskim i srednjim primanjima koji trebaju multikulturalno/međugrupno organiziranje i razvoj. Za obespravljene, sada kao i uvijek moć dolazi s brojem, a praktičari u zajednici trebaju biti upoznati s potencijalnim političkim i ekonomskim strategijama koje se mogu koristiti kako bi se podijelile različite populacijske grupe i kako bi ih se okrenulo jedne protiv drugih. Snaga društva može biti u različitosti, ali samo ukoliko različite populacije i grupe s niskim prihodima imaju mogućnosti za veću socijalnu i ekonomsku vidljivost. Borbe različitih rasa u zajednicama i onih koji žive u siromaštvu ili blizu siromaštava u suvremenom društvu kako bi postigli građansku i političku jednakost, pristup institucijama i ekonomsku mogućnost daleko su od dovršenih (Abromovitz, 1986.; Blank, 1997.; Gutierrez i Lewis, 1999.; Piven i Cloward 1979.; Rivera i Erlich, 1998.). Veoma malo zajednica u razvijenim državama svijeta može se smatrati tako homogenim da za njihovu analizu može biti dovoljno samo jednokulturalna perspektiva. Kulturalna svijest i kulturalna kompetencija postale su neophodne vještine (Fong i Furuto, 2001.). Međutim kako je literatura o lateralnoj kompetenciji i multikulturalizmu integrirana u kurikulum i praksu različitih pomagačkih profesija veoma je važno za te pristupe da ih se jednostavno ne usmjeri na razumijevanje i prilagodbu u vještinama direktne prakse kako bi bili odgovarajući za različite klijente. Puno je važnije održati čvrstu i jasnu usmjerenost na socijalnu pravdu (Finn i Jacobson, 2003.; Hardy-Fanta, 1986.; Longres, 1997.) te na potrebu za praksom u zajednici, političkom i socijalnom akcijom i političkom praksom koja se bavi pitanjima osnaživanja zajednice, jednakosti i mogućnosti. Jednako tako važno je analizirati svaki model prakse u zajednici ili planirane intervencije kako bismo bili sigurni da su modeli i pristupi relevantni za različite populacije i perspektive.

Široki raspon perspektiva koje su sukladne s makropraksom istražili su Anderson i Carter (2003.) u svojem radu o različitostima, uključujući tri glavne kategorije: etnokulturalnu, ugnjetavanje i ranjive životne situacije. Oni su nadalje podijeljene u 12 detaljnijih perspektiva: snage, osnaživanje, etnička osjetljivost, vrijednosna orijentacija, ljudi različite boje kože, dualna perspektiva, etnocentrizam, socijalna pravda, etnografija, komunikacija, feminizam i 
konstruktivizam. Ove su perspektive korisne kada analiziramo modele prakse u zajednici kao pristupe različitostima i multikulturalizmu.

\subsection{Feministički kontekst i kontekst ljudskih prava}

Budući da polovicu svjetske populacije čine žene rodna pitanja će biti glavni fokus kroz koji se moraju promatrati i procjenjivati svi modeli prakse u zajednici. U većini društava žene su uvijek bile uključene u pitanja zajednice i u rješavanje problema. U mnogim zemljama puno žena bile su vođe u razvoju prakse u zajednici i nastavile su to biti u glavnim smjerovima kako interorganizacijskog rada tako i rada na najnižim razinama. Sve do nedavno većina literature bila je napisana od strane muškaraca, međutim tijekom drugog vala američkog feminizma žene znanstvenice i aktivistice dale su veliki doprinos literaturi u vezi prakse u zajednici i makro prakse. Povijest feminizma bila je duga borba kako u obiteljskim tako i u javnim sferama u vezi sa zahtjevima da se ženama prizna status jednakih bića, građana i dionika u društvu i u svijetu. U posljednjih dvadeset godina 20. stoljeća vidljiv je razvoj povećane primjene feminističkih radova. Rast ove literature nastavlja se brzo početkom 21. stoljeća kad žene preuzimaju vodeće položaje u praksi i na fakultetima te kad je više feminističke literature integrirano u preddiplomske i diplomske programe na muškim i ženskim fakultetima. Tijekom tog razdoblja feministička literatura značajno je doprinijela razvoju i analizi znanstvene osnove u vezi pitanja žena kao klijentica, radnica, voditeljica i praktičarki u zajednici (Abromovitz, 1986.; Brandwein, 1981.; Chandler, 1986.; Ellsworth, Hooyman, Ruff, Stam i Tucker, 1981.; Gutierrez i Lewis, 1999.; Hyde, 1996., 2000.). Feministički pristupi mogu se primijeniti u svim područjima prakse u zajednici. 1996. godine Hyde je izradio analizu Rothmanovih isprepletenih modela intervencija u zajednici i napisao da feministički modeli nemaju toliko specifični „prostor“ u „razvojno-akcijskoj“ kategoriji nego zapravo postoje i napreduju u svim modelima prakse u zajednici. Kao što pokazuju brojni primjeri raspon feminističke prakse u zajednici je širok. Kako bi analizirali pristupe prakse u zajednici za potrebe razmatranja rodnih pitanja, Weil, Gamble i Williams (1998.) razvili su skup pitanja koja potiču uključivanje feminističkog sadržaja i predstavljanja žena i djevojaka u svih osam modela prakse u zajednici.

Preokret u svijesti, politici i praksi koji se dogodio širom svijeta kad su žene opetovano „zatražile pola ljudskog iskustva“ (Figueira-McDonough, Netting i Nichols-Casebold, 1998.) nije samo otkrio mogućnosti žena, nego je i osvijetlio značajne doprinose koje su žene dale praksi u zajednici od najranije povijesti. „Ljudska prava su ženska prava“ predstavlja svojevrsni poziv kojeg treba čuti na 
mnogim međunarodnim skupovima. Žene diljem svijeta traže jednakost i osnovna prava i tražit će to sve više kako obrazovanje i ekonomske mogućnosti postaju dostupnije ženama i na južnoj polutci. lako korijeni ranije spomenutih modela prakse u zajednici govore o značajnoj povijesti, treba se staviti novi naglasak na vrijednosti i ciljeve prakse u zajednici uzimajući u obzir složene demografske, političke, ekonomske i socijalne promjene s kojima se suočavaju stručnjaci u ovom stoljeću. Etnički i rasni raskoli, klasne i rodne podjele te važnost pristupa sustavima podrške za početak i kraj života u svim društvima traže fokus na najkritičnija područja za razumijevanje i uključivanje u praksu u zajednici. Ta pitanja prakse u zajednici odjeknula su na određeni način i u tekstu Opće deklaracije o ljudskim pravima (United Nations, 1948.). Praksa u zajednici u 21. stoljeću trebat će se pažljivo usmjeriti na sve razine pritiska za pozitivnom socijalnom promjenom i širenje ljudskih prava.

\subsection{Globalizacija}

Svi modeli rada u zajednici pod utjecajem su globalizacije koju je moguće definirati kao „proces kroz koji su svi ljudi i zajednice diljem svijeta stekli iskustvo povećanog zajedništva u ekonomskom, socijalnom i kulturnom okruženju" (IFSW, 2002.). Kao što ova definicija naznačuje, globalizacija nudi značajno dugoročno obećanje - za ljudska prava, za rad na održivom razvoju te za priznavanje zajedničke humanosti putem komunikacije i interakcije (Burbidge, 1997.; Henderson, 1996.). Međutim, na početku prvog desetljeća 21. stoljeća ekonomski, politički i socijalni rizici izgledaju visoki osobito za ranjive populacije kao što su siromašni, osobe s invaliditetom, obitelji, djeca i mladi, izbjeglice i migranti, oni koji su prodani kao roblje i drugi (Cockburn, 2003). Ukratko, globalizacija nudi mogućnosti kako za globalni humani napredak tako i za povećanje nejednakosti u prihodima i mogućnostima diljem svijeta.

Treću mogućnost za analiziranje modela prakse rada u zajednici predstavlja zbog toga globalizacija. Proces globalizacije - mogućnost za brzi prijenos informacija, povećanu međupovezanost između ljudi i kultura, smanjenje važnosti granica i nacionalnih barijera te povećavanje snage globalnih korporacija zahtjeva uključivanje u lokalne aktivnosti, povezivanje sa socijalnim problemima i pitanjima na nacionalnoj i međunarodnoj razini te biti u mogućnosti razumjeti i procijeniti globalna pitanja.

Niti jedna zajednica nije izolirana od pitanja i rezultata globalizacije i pitanja kao što su ova: Kako su i gdje članovi zajednice zaposleni? Što je dostupno od hrane i odakle ona dolazi? Kako će izgledati obrazovni programi? Tko su susjedi 
i odakle su? Kako se održava obitelj i organizacijske mreže? Kako se mogu osigurati poštene plaće i radni uvjeti? Kako je populacija demografski sastavljena?; sva ta pitanja zahvaćena su utjecajima globalizacije. Niti jedan stručnjak koji radi u u zajednici i koji se želi uključiti u bilo koji od osam modela prakse u zajednici ne može raditi bez poznavanja globalnog političkog, socijalnog i ekonomskog konteksta i njegovog utjecaja na lokalnu ekonomiju i zajednicu. Pored toga da bi se postalo partner u zajednici i provodilo praksu u zajednici treba se barem razumjeti principe i postavke Opće deklaracije o ljudskim pravima, pratiti rezultate izvještaja o socijalnom razvoju UN-a kao i ključna pitanja u vlastitom području rada. Završno, kako rodna tako i multikulturalna pitanja važna su i neizostavna stvarnost globalnog konteksta ljudske egzistencije u 21. stoljeću. Suvremena literatura je prepuna rasprava o ekonomskim, demografskim te političkim i kulturnim promjenama diljem svijeta. Praksa u zajednici treba voditi računa o navedenim kontekstima kao i o svim modelima, pristupima i praksama.

\section{KLJUČNE VRIJEDNOSTI I CILJEVI PRAKSE U ZAJEDNICI}

Vrijednosna osnova prakse u zajednici ne odnosi se samo dostojanstvo pojedinca, nego se usmjerava i na međuovisnost obitelji i zajednica (npr. ljudskih odnosa) te na razvoj poštenja, pravednosti i jednakosti (npr. socijalna pravda) (Allen-Meares i DeRoos, 1997.; Drake, 2001.; Flynn, 1995.; IFSW, 2003.; NASW, 1996.; Weil i Gamble, 1995.).

Kako bi se povezali s grupama u zajednici stručnjaci moraju biti u stanju definirati specifične ciljeve takvog angažmana. Ti ciljevi trebaju biti razvijeni u suradnji s onima s kime stručnjak radi te trebaju pružiti ključnu motivaciju za praktičare i članove zajednice i dolaženje do zajedničkog, obostrano prihvaćenog cilja. U djelovanju na jačanju sustava usluga, aktivnosti treba poduzimati zajedno s predstavnicima populacija ili grupa koje te usluge koriste. Ciljevi ne trebaju biti skriveni ili apstraktni izrazi, nego otvoreni, transparentni i direktni dogovor radnika sa zajednicom i članovima organizacije.

Praktičari u zajednici mogu očekivati suradnju sa specifičnim grupama te $\mathrm{s}$ intergrupnim i multikulturalnim entitetima koji imaju kompetitivne poglede na pitanja te često različite strategije kako riješiti probleme. Stručnjak koji je usmjeren na vrijednosti i ciljeve i koji ih eksplicitno izražava u suradnji sa grupama u zajednici imat će veću sposobnost razviti međusobno respektirajuće odnose s članovima grupe te time djelovati kao stručnjak koji omogućava pronaći zadovoljavajući zajednički temelj za uspješnu akciju. 
Tri kritična konteksta koja su opisana ranije, kao i vrijednosti i ciljevi rada u zajednici, trebaju pružiti polazište za analizu osam modela. lako su modeli, kao što ističe Weber (1949.), „idealni tipovi“, aktualna praksa se može uspješno usporediti s modelima kako bi se utvrdili glavni aspekti pristupa koji su primijenjeni i ispitali kako bi se vidjele važne faze, sastavnice ili elementi koji su zanemareni te se trebaju uvrstiti u trenutni rad. Kao što navode Netting i sur. (2004): „modeli pružaju uputu i usmjerenje praktičaru. Teorije pružaju alat za razmišljanje o problemu ili potrebi dok modeli pružaju uputu za akciju i intervenciju“.

Ciljevi prakse u zajednici mogu se prema Weil i Gamble (2002) postaviti u okviru osam različitih područja. To su: a) poboljšanje kvalitete života od pojedinačnih lokalnih pitanja, kao što su osiguravanje sigurnih prijelaza ceste u ruralnim zajednicama, do kompleksnih socijalnih pitanja poput osmišljavanja strategija za poboljšanje obrazovanja i mogućnosti za različite etničke skupine ili oblikovanje i primjena globalnih strategija za održivi razvoj; b) proširivanje ljudskih prava kroz razvijanje participativnih struktura i mogućnosti te produbljivanje demokracije za građane koji su isključeni i osjećaju bespomoćnost u utjecanju na politike koje imaju utjecaj na njihove živote; odgovaranje na potrebe značajnog broja ekonomskih i političkih izbjeglica u svijetu; dokidanje ropstva; te proširivanje ljudskih prava na žene i djecu; c) zastupanje interesnih zajednica poput djece $s$ različitim emocionalnim ili bihevioralnim problemima; specifičnih pitanja kao što su ljudska prava za homoseksualce; za stjecanje resursa kao što su aktivnosti na planu financiranja projekata ekonomskog razvoja manjinskih grupa ili uspostavljanje političkih i socijalnih prava za žene i marginalizirane populacije diljem svijeta; d) socijalni i ekonomski razvoj s ciljem osiguravanja socijalne podrške i ekonomske održivosti putem širenja participacije i izgradnje vodstva na najnižim razinama u zajednicama, regijama te na globalnoj razini; korištenje alata poslovnog razvoja; izgradnja ekonomskih, socijalnih i političkih resursa za siromašne u osiromašenim urbanim i ruralnim područjima diljem svijeta; primjena nacrta Agende 21 UN-a za održivi socijalni i ekonomski razvoj; e) planiranje usluga $i$ programa za novoprepoznate i rekonceptualizirane potrebe ili potreba koje će koristiti novoj populaciji koja se pojavila: aktivnosti uključuju zdravstvene i socijalne usluge; razvoj alternativnih usluga za zlostavljane žene: oblikovanje službi za posvojenje, udomiteljstvo, mentalno zdravlje ili za mlade; f) integracija usluga putem razvijanja lokalnih, nacionalnih i internacionalnih sredstava koordiniranja službi za populacije u potrebi; primjeri za to su izgradnja sustava podrške za obitelji, za zaštitu i dobrobit djece; izgradnja mreže dobro povezanih zdravstvenih službi i ugroženog staračkog stanovništva; te osiguravanje hrane, zaštite, premještanje usluga za izbjeglice; g) politička i socijalna akcija s ciljem izgradnje po- 
litičke moći za ekonomski i socijalno marginalizirane, zaštita slabih i siromašnih, njegovanje institucionalne promjene radi uključivanja i jednakosti te povećavanje participativne demokracije kao i jednakosti u pristupu i mogućnostima na lokalnim, regionalnim i međunarodnim razinama - poput političkog organiziranja u različitim multikulturnim zajednicama, provođenje nacionalnih istraživanja i organiziranja u vezi prava, zaštita i dobrobit djece, aktivnosti u vezi prevencije torture te oslobađanje političkih zatvorenika diljem svijeta te h) socijalna pravda s ciljem izgradnje jednakosti i mogućnosti za sve rase, etničke zajednice, različite rodove i nacionalnosti - npr. osiguravanje prava glasa ženama, podizanje prava radnika na nacionalnoj i globalnoj razini te primjena članaka Opće deklaracije o ljudskim pravima kroz razvoj socijalnih programa te nacionalnih i međunarodnih intervencija.

\section{MODELI PRAKSE ZA 21. STOLJEĆE}

Praksa u zajednici obuhvaća pristupe i metode u rasponu od popularnog obrazovanja i organizacija koje se bave organiziranjem i razvojem na lokalnoj razini preko službi koje se bave planiranjem i koordinacijom do političkog djelovanja. Ona obuhvaća vrijednosti intervencija zasnovanih na osnaživanju participacije u demokratskim procesima, reformu sustava socijalnih službi, pomaganje grupama i zajednicama u zadovoljavanju njihovih potreba i organiziranju za socijalnu pravdu.

Moguće je utvrditi razlike među brojnim, u praksi isprobanim, modelima koji se smatraju glavnim za postizanje uspjeha u zajednici. Ujedno, ispitivanje modela otkriva preklapanje u nekim konceptualnim komponentama. Svaki model također predstavlja specifični, koherentni i jasan pristup praksi u zajednici. lako Hardcastle, Wenocur i Powers, (1997.) te Homan (2004.) ističu kako također postoji značajna pomiješanost i faznost modela u praktičnim situacijama, korisno je ispitati koje su komponente kritične u specifičnom modelu za specifičnu intervenciju u zajednici. Praktičari trebaju znati što rade i zašto to rade, a ciljevi intervencije, područje rada i metodologija će se razlikovati u različitim modelima. Modeli rada u zajednici mogu se iskoristiti u određivanju različitih željenih ciljeva, pojašnjavanju dionika, grupa ili organizacija koje se namjeravaju mijenjati kao i u odabiru strategija za koje se najviše može očekivati da će biti uspješne uzimajući u obzir zadani kontekst i odabrani model intervencija. 


\section{ZAKLUUČAK}

Razvoj zajednice i promocija zdravlja u zajednici predstavljaju suštinski aspekt suvremene prakse i politike zdravlja. Sve složeniji uvjeti u kojima se članovi zajednice, a osobito oni unutar najranjivijih skupina poput obitelji, djece i mladih, suočavaju sa zdravstvenim rizicima $s$ jedne strane te sve veći problemi $u$ području financiranja zdravstvenih programa utjecali su na kreiranje brojnih modela koji su se u okviru „novih pristupa utemeljenih na radu u zajednici“ dokazali koristeći zajednicu kao ishodišnu točku svojih intervencija. Interdisciplinarnost i prepoznavanje međuovisnosti različitih sustava zajednice na zdravlje i ukupnu dobrobit stanovništva prepoznati su kao odrednice ovih modela, a različita načela koja svoje korijene vuku iz tradicija borbe za ljudska prava postavljeni su u središte vrijednosnog određenja modernog čovjeka i njegovog prava na zdravlje.

\section{REFERENCE}

1/ M. ABROMOWITZ (1986): Regulating the lives of women: Social welfare policy from colonial times to the present, Boston: South End Press.

2/ P. ALLEN-MEARES \& Y. DEROOS (1997): The future of the social work profession, in M.reisch \& E. Gambrill (Eds.), Social work in the 21st century (pp. 376-386), Tousand Oaks, CA: Pine Forge Press.

3/ American Hospital Association (2000): American Hospital Association Annual Survey Database, Fiscal Year 2000. Chicago: Health Forum.

4/ E. T. ANDERSON \& J. MCFARLANE (2004): Community as partner. Philadelphia: Lippincott Williams \& Wilkins.

5/ J. ANDERSON \& R. W. CARTER (Eds.) (2003): Diversity perspectives for social work practice, Boston: Allyn \& Bacon.

6/ N. AWOFESO (2003): The healthy cities approach-reflections on a framework for improving global health. Bulletin of the World Health Organization 81(3), 1-6.

7/ N. AWOFESO (2004): What's new about the "New Public Health"? American Journal of Public Health 94 (5), 705-709.

8/ M. J. BAISCH, (2009): Community health: an evolutionary concept analysis. Journal of Advanced Nursing 65(11), 2464-2476.

9/ M. BARNES, (1997): Care, Communities and Citizens; London, Longman.

10/ R. BEAGLEHOLE, R. BONITA, R. HORTON, O. ADAMS \& M. MCKEE (2004): Public health in the new era: improving health through collective action. The Lancet 363, 2084-2086. 
11/ L. BERTINATO, (2000): The Verona Initiative: the process of developing partnerships at local level; Promotion \& Education , 7: 51-52.

12/ N. BETTEN \& M. J. AUSTIN (Eds.) (1990): The Roots of community organizing, 1917-1939. Philadelphia: Temple University Press.

13/ D. BLACK (1980): Inequalities in Health. London: HMSO.

14/ R. M. BLANK, (1997): It takes a nation: A new agenda for fighting poverty, Princeton, NJ: Princeton University Press.

15/ G. BRAGER \& H. SPECHT (1973): Community organizing, New York: Columbia University Press.

16/ R. A. BRANDWEIN (1981): Toward androgyny in community and organizational practice, in A. Weick \& S.T. VanDiver (Eds.) Women, power and change (pp. 158-170), Washington DC: MASW.

17/ Briggs, X.d.S. (1997): Social Capital and the Cities: Advice to Change Agents, Harvard University, International Workshop on Community Building, The Rockefeller Foundation, Bellagio, Italy, October 1997.

18/ U. BRONFENBRENNER (1989): Ecological systems theory. Annals of Child Development, 6, 187-249.

19/ J. BURBIDGE, (Ed.) (1997): Beyond prince and merchant: Citizen participation and the rise of civil society, New York: Pact.

20/ F. D. BUTTERFOSS, \& M. C. KEGLER, (2002): Toward a comprehensive understanding of community coalitions: Moving from practice to theory, u R. J, DiClementc, K. A, Crosby, \& M, C, Kegler, (Kds,), Emerging Theories in Health Promotion Practice and Research: Strategies for impromng Public Health (pp, 157-93). San Francisco: Jossey-Bass.

21/ I. B. CARLETON-LANEY, (Ed.) (2001): African American leadership: An empowerment tradition in social welfare histoty, Washington DC: NASW Press.

22/ R. CHAMBERS, (2001): Involving patients and the public - is it worth the effort? Journal of the Royal Society of Medicine, 94, 375-377.

23/ S. CHANDLER, (1986): The hidden feminist agenda in social development, in N. VanDen Bergh \& L-B. Cooper (Eds.), Feminist visions for social work (pp. 149-162), Washington, DC: NASW Press.

24/ A. COCKBURN, (2003): 21st-century slaves, National Geographic, 204(3), 2-24.

25/ L. COTTRELL, (1976): The Competent Community u: Kaplan, B., Wilson, R.N. i Leighton, A.H. (eds).: Further Explorations in Social Psychiatry; New York, Basic Books, 195-209.

26/ R. A. COUTO (2000): Community health as social justice: lessons on leadership. Family and Community Health 23, 1-17. 
27/ F. M. COX, J. L. ERLICH, J. ROTHMAN, TROPMAN, J. E. (1987): Strategies of Community Organization; Itasca, Illinois, 4th ed. F.E. Peacock Publishers Inc.

28/ R. DAHRENDORF, (1997): After 1989. Morals, Revolution and Civil Society; New York, St. Martin's Press.

29/ R. F. DRAKE, (2001): The principles of social policy, New York: Palgrave

30/ J. L. ECKLEIN, \& A. A. LAUFFER, (1972): Community organizers and social planners, New York: John Wiley.

31/ C. ELLSWORTH, N. HOOYMAN, R.A. RUFF, S. B. STAM, \& J. H. TUCKER (1981): Toward a feminist model for planning for and with women, in A. Weick \& S.T. VanDiver (Eds.), Women, power and change (pp. 146-157), Washington DC: NASW Press.

32/ J. FIGUEIRA-MCDONOUGH, F. E. NETTING \& A. NICHOLS-CASEBOLT (Eds.), The role of gender in practice knowledge: Claiming half the human experience (pp. 241-286), New York: Garland.

33/ J. L. Finn, \& M. Jacobson, (2003): Just practice: A social justice approach to social work, Peosta, IA: Eddie Bowers.

34/ J. FLYNN (1995): Social justice in social agencies, in R.L. Edwards (Ed.), Encyclopedia of social work (19th ed., pp.2173-2179), Washington, DC: NASW Press.

35/ R. FONG \& S. B. C. L. FURUTO (Eds.) (2001): Cultutally competent practice: Skills, interventions and evaluations, Needham Heights, MA: Ally \& Bacon.

36/ GARDNER J. W., (1991): Building Community; Washington, Independent Sector.

37/ E. GELLNER, (1994): Conditions of liberty: Civil society and its rivals, New York: Allen Lane/Penguin Press.

38/ R. GOODMAN, A. WANDERSMAN, M. CHINMAN, P. IMM \& E. MORRISSEY (1996): An ecological assessment of community-based interventions for prevention \& health promotion: an approach to measuring community coalitions. American Journal of Community Psychology 24 (1), 33-61.

39/ L. M. GUTIERREZ \& E. A. LEWIS (1999): Empowering women of color, New York: Columbia University Press.

40/ D. A. HARDCASTLE, S. WENOCUR \& P. R. POWERS (1997): Community practice: Theories and skills for social workers, New York: Oxford University Press.

41/ C. HARDY-FANTA (1986): Social action in Hispanic groups, Social Work, 31(2), 119-123.

42/ E. B. HARPER, \& A. DUNHAM (1959): Community organization in action, New York: Association Press. 
43/ P. HAWE, L. KING, M. NOORT, C. JORDENS, B. LLOYD (1999): Indicators to Help with Capacity Building in Health Promotion. Health Promotion Branch, New South Wales Health Department. Australia; http://www.health.nsw. gov.au/pubs/i/pdf/capbuild.pdf. (pristupljeno 15.09.2019.)

44/ H. HENDERSON, (1996): Building a win-win world: Life beyond global economic warfare, San Francisco: Barret-Koehler.

45/ M. S. HOMAN, (2004): Promoting community change: Making it happen in the real world (3rd ed.), Belmont, CA: Brooks Cole/Thompson.

46/ M. S. HOMAN, (2004): Promoting community change: Making it happen in the real world (3rd ed.), Belmont, CA: Brooks Cole/Thompson.

47/ C. HYDE, (1996): A feminist response to Rothman's „The interweaving of community intervention approaches", Journal of Community Practice, 3(3/4), 127-145.

48/ C. HYDE, (2000): Feminist approaches to social policy, in J. Midgeley, M.S. Tracy \& M. Livermore (Eds.), The handbook of social policy (pp. 421-434), Thousand Oaks, CA: Sage.

49/ Institute of Medicine. Committee on Assuring the Health of the Public in the 21st Century (2003): The Future of the Public's Health in the 21st Century, Washington DC, National Academies Press.

50/ International federation of Social Workers (IFSW) (2002): Countering the negative effects of globalisation, IFSW News 2(3), 3.

51/ International Federation of Social Workers (IFSW) (2003): Ethics in social work: Statement of principles, http://www.ifsw.org?GM-2004//GM-Ethicsdraft.html, (pristupljeno 27.09.2019).

52/ S. Kahn, (1982): Organizing: A Guide for Grassroots Leaders. New York: McGraw-Hill.

53/ S. B. KAR, C. A. PASCUAL \& K. L. CHICKERING (1999): Empowerment of women for health promotion: a meta-analysis. Social Science and Medicine, 49, 1431-1460.

54/ R. M. KRAMER (1966): Community organizing and administration: Integration or separate but equal?, Education for social work, 2, 48-56.

55/ J. KULIG (2000): Community resiliency: The potential for community health nursing theory development. Public Health Nursing, 17, 374-385.

56/ R. LABONTE \& G. LAVERACK (2001): Capacity building in health promotion, Part 1: for whom and for what purpose. Critical Public Health 11 (2), 111127.

57/ R. LABONTE \& G. LAVERACK, (2000): A planning framework for community empowerment goals within health promotion. Healthy Policy Plan, 5(3), 255-262. 
58/ M. LALONDE (1974): A new perspective on the health of Canadians. Ottawa, Canada. Government of Canada.

59/ J. F. LONGRES (1997): The impact and implications of multiculturalism, in M. Reisch \& E. Gambrill (Eds.), Social Work in the 21st century (pp. 39-47), Tousand Oaks, CA: Pine Forge Press.

60/ A. R. MASONA, R. C. HILLA, L. A. MYERSB, \& A. D. STREETA (2008): Establishing the economics of engaging communities in health promotion: what is desirable, what is feasible? Critical Public Health Vol. 18, No. 3, 285-297.

61/ C. MERZEL \& J. D’AFFLITTI (2003): Reconsidering Community-Based Health Promotion: Promise, Performance, and Potential. American Journal of Public Health, Vol 93, No. 4 p. 557-574.

62/ M. MINKLER \& N. WALLERSTEIN (1997): Improving health through community organisation and community building, u K, Cîlanz, I. M. Lewis, B. K, Rimer, (Eds,), Health hehavior and Health Education: Theory, Research and Practice, San Francisco, Jossey-Bass.

63/ National Association of Social Workers (NASW) (1996): Code of Ethics, Washington, DC: Author.

64/ F. E. NETTING, P. M. KETTNER, \& S.L. MCMURTY, (2004): Social work macro practice, Boston: Allyn \& Bacon.

65/ B. NEUMAN, (1995): The Neuman systems model (3rd ed.). Norwalk, CT: Appleton \& Lange.

66/ B. I. NORTON, K. R. MCLEROY, J. N. BURDINE, M. R. J. FELIX, \& A. M. DORESY, (2002). Community Capacity: Concept. Theory, and Methods, u R, J, DiClemente, R, A, Crosby, M. C, Kegler, (lids). Emerging Theories in Health Promotion Practice and Research: Strategies for improving Puhlic Health (pp, 19-1-227), San Francisco: Jossey-Bass.

67/ P. C. OLDEN, \& D. C. CLEMENT (2000): “The Prevalence of Hospital Health Promotion and Disease Prevention Services: Cood News, Bad News and Policy Implications" The Milbank Quarterly 78 (1): 115-46.

68/ World Health Organization (1986): Ottawa charter for health promotion; http://www.who.int/hpr/NPH/docs/ottawa_charter_hp.pdf (pristupljeno 10. 09. 2019.).

69/ R. J. Patti, (1983): Social wlfare administration: Managing social program sin a developmental context, Englewood Cliffs, NJ: Prentice Hall.

70/ F. F. PIVEN, \& R. S. CLOWARD, (1979): Poor people's movements: Why they succeed, how they fail, New York: Vintage.

71/ E. I. PROENCA (1998): "Community Orientation in Health Services Organizations: The Concept and Its Implementation." Health Care Management Review 23 (2): 28-38. 
72/ E. J. PROENCA, M. D. ROSKO, \& J. ZINN (2000): “Community Orientation in Hospitals: An Institutional and Resource Dependence Perspective." Health Services Research 35 (5): 1011-35.

73/ R. PUTNAM (1993): Making democracy work: civic tradition in modern Italy. Princeton: Princeton University Press.

74/ R. PUTNAM (1995): Tuning in, tuning out: The strange disappearance of social capital in America. Political Science and Politics, 28(4): 664-683.

75/ F. E. RACHER, \& ANNIS (2007): Community Health Action Model: Health Promotion by the Community; http://www.brandonu.ca/rdi/files/2011/08/ CHA_ModeWorkingPaper.pdf, (pristupljeno 18. 09. 2019.)

76/ F.E. Racher, RN \& R. C. Annis (2008): Research and Theory for Nursing Practice: An International Journal, Vol. 22, No. 3, 2008.

77/ A. R. Rafael (2000): Watson's philosophy, science, and theory of human caring as a conceptual framework for guiding community health nursing practice. Advances in Nursing Science 23(2), 34-49.

78/ R. RENWICK, \& I. BROWN, (1996): The Centre for Health Promotion's conceptual approach to quality of life: Being, belonging, and becoming, u R. Renwick, I. Brown, \& M. Nagler (Eds.), Quality of life in health promotion and rehabilitation: Conceptual approaches, issues, and applications (pp. 75-88). Thousand Oaks, CA: Sage.

79/ V. Ridde (2007): Reducing social inequalities in health: public health, community health or health promotion? IUHPE - Promotion \& Education, vol. XIV, no. 2, p 63-67

80/ F. G. RIVERA, \& J. L. ERLICH, (Eds.) (1998): Community organizing in a diverse society (3rd ed.), Boston: Allyn \& Bacon.

81/ A. ROBERTSON \& M. MINKLER, (1994): New health promotion movement: a critical examination. Health Education Quarterly, 21, 295-312.

82/ I. ROOTMAN \& J. RAEBURN (1994): The concept of health, u: Pederson, A., O'Neill, M. \& Rutten, A. (1995). The implementation of health promotion: a new structural perspective. Social Science \& Medicine, 41(12), 1627-1637.

83/ M. G. ROSS (1955): Community organization: Theory and principles, New York: Harper \& Brothers.

84/ M. G. ROSS (1958): Case hisories in community organization, New York: Harper \& Row.

85/ J. ROTHMAN, (1968): Three models of community organization practice, in National conference on social welfare, social work practice 1968, New York: Columbia University Press. 
86/ J. ROTHMAN, (2001): Approaches to community intervention, in J. Rothman, J.L. Erlich \& J.E. Tropman (Eds.), Strategies of community intervention (pp. 27-64), Itasca, IL: F.E.Peacock.

87/ J. ROTHMAN, I J. TROPMAN, (1987): Models of Community Organization and Macro Practice Perspectives: Their Mixing and Phasing u: Cox, F.M. et al.: Strategies of Community Organization; Itasca, Illinois, 4th ed. F.E. Peacock Publishers Inc., 3-26

88/ H. J. RUBIN, \& I. S. RUBIN, (2001): Community organizing and development (3rd ed.), Boston: Allyn \& Bacon.

89/ H. J. RUBIN, (2000): Renewing hope within neighbourhood of despair: The community-based development model, Albany, SUNY Press.

90/ K. RYAN-NICHOLLS, \& F. E. RACHER (2004). Investigating the health of rural communities: Toward framework development. Rural and Remote Health, 4. http://www.rrh.org.au/articles/showarticlenew.asp?ArticleID=244, (pristupljeno 15. 09. 2019.).

91/ J. D. SEAY \& R. M. SIGMOND. (1989): “Community Benefit Standards for Hospitals: Perceptions and Performance." Frontiers of Health Services Management 5 (3): 3-39.

92/ S. SLAVIN, (Ed.) (1985): Social administration: The management of the social services, New York: Haworth.

93/ G. SORENSEN, K. EMMONS, , Hunt, M.K., \& Johnston, D. (1998). Implications of the results of community intervention trials. Annual Review of Public Health, 19, 379-416.

94/ J. SOUTH, A. MEAH, \& P. BRANNEY (2009): People In Public Health. Expert Hearings: A Summary Report. Centre for Health Promotion Research, Leeds Metropolitan University, Leeds. www.Imu.ac.uk/health (Pristupljeno: 12. 09. 2019.)

95/ S. H. TAYLOR, \& R. W. ROBERTS (Eds.) (1985): Theory and practice of community social work, New York: Columbia University Press.

96/ B. K. TONES (1986): Health education and the ideology of health promotion: a review of alternative approaches. Health Education Research 1 (1), 3-12.

97/ T. H. TULCHINSKY \& E. A. VARAVIKOVA (2010): What is the "New Public Health"? Public Health Reviews 32: p.25-53.

98/ B. TURNOCK (2001) Public Health: What it is and How it Works. Jones \& Bartlett, Sudbury, MA.

99/ United Nations (1948): Universal declaration of human rights; United Nations General Assembly Resolution 217 A(111). 
100/ M. WEBER, (1949): Methodology of the social sciences, New York: Free Press.

101/ M. WEIL \& D. GAMBLE (1995): Community practice models, in R.L. Edwards (Ed.), Encyclopedia of social work (19th ed., pp. 577-593), Washington DC: NASW Press.

102/ M. WEIL (1997): Community building: Building community practice, in P.L. Ewalt, E.M. Freeman, S.A. Kirk \& D.L. Poole (Eds.), Social policy, reform, research and practice (pp 35-61), Washington, DC: NASW Press.

103/ M. WEIL, D. N. GAMBLE, \& E. S. WILLIAMS (1998): Women, communities and development, in J. Figueira-McDonough, F.E. Netting \& A. Nichols-Casebolt (Eds.), The role of gender in practice knowledge: Claiming half the human experience (pp. 241-286), New York: Garland.

104/ M. O. WEIL \& D. N. GAMBLE (2002): Community practice models for the 21st century in A.R. Roberts \& G.J. Greene (Eds.): Social workers' desk reference (pp.525-534), New York: Oxford University Press.

105/ World Health Organization (WHO) (1986): Ottawa Charter for Health Promotion: An International Conference on Health Promotion, the Move Towards A New Public Health. World Health Organization, Ottawa, Canada 17-21 November.

106/ World Health Organization (WHO) (1997): Jakarta Declaration on Leading Health Promotion into the 21st Century. In Fourth International Conference on Health Promotion: New Players for a New Era-Leading Health Promotion Into the 21st Century (ed.), World Health Organization, Jakarta http://www.who.int/healthpromotion/conferences/previous/jakarta/declaration/en/print.html. (Pristupljeno 19. 09. 2019.) 


\section{SAŽETAK \\ NEKE ODREDNICE RAZVOJA ZAJEDNICE I PROMOCIJE ZDRAVLJA OBITELJI, DJECE I MLADIH}

Suvremeni pristupi određenju zdravlja već su dugo pod utjecajem shvaćanja koji ga opisuju kao stanje potpunog tjelesnog, duševnog i socijalnog blagostanja, a ne samo odsustva bolesti. Naročito osjetljive društvene skupine poput obitelji, djece i mladih, ali i brojne specifične kategorije stanovništva poput izbjeglica, siromašnih, etničkih, seksualnih ili rasnih manjinskih skupina pogođene su dodatno u zajednicama u kojima žive upravo putem utjecaja koji prema njima vrše članovi te iste zajednice. Zbog toga su se tijekom posljednjih desetljeća u teoriji i praksi različitih profesija koje se bave zdravljem stanovništva (kao što su to medicina, socijalni rad, psihologija i druge) razvili pristupi i modeli koji zdravlju pristupaju unutar paradigme razvoja zajednice i promocije zdravlja. Time su na neki način zajednica i koncept zdravlja postali nerazdvojivo povezani. Zdravlje u zajednici predstavlja sposobnost zajednice da stvori i uspješno koristi resurse s ciljem podrške dobrobiti i kvalitete života zajednice. Razvoj zajednice odnosi se na proces njegovanja osjećaja zajednice, jačanja socijalnih veza među ljudima, podizanja kohezije s ciljem postizanja harmonične, podržavajuće, i za život poticajne i zanimljive okoline ljudima. On se zasniva na razvoju resursa u zajednici koji se mogu između ostalog pronaći u grupama za samopomoć, sustavu socijalne podrške ili razvoju sustava koji jačaju sudjelovanje građana u usmjeravanju i oblikovanju zdravstvenih prioriteta. Promocija zdravlja u zajednici predstavlja konceptualni okvir koji naglašava primarnu prevenciju i perspektivu utemeljenu na suradnji sa stanovništvom, a na nju se može gledati kao na filozofiju, proces, projekt ili ishod. Razvoj zajednice i promocija zdravlja u zajednici sadrže fundamentalno vjerovanje da ljudi mogu identificirati i rješavati svoje probleme. S tim ciljem razvijeni su brojni modeli rada u zajednici od kojih su neki postavljeni ideal-tipski, a neki su proizašli iz prakse rada stručnjaka diljem svijeta. U radu su prikazane neke ključne odrednice koncepata razvoja zajednice i promocije zdravlja, obilježja konteksta u kojima se procesi razvoja zajednice i promocije zdravlja odvijaju, specifičnosti pojedinih modela rada, njihovih ključnih vrijednosnih odrednica i njihovi ciljevi. Zaključno, istaknuto je kako razvoj zajednice i promocija zdravlja u zajednici predstavljaju suštinski aspekt suvremene prakse i politike zdravlja te kako se koristeći zajednicu kao ishodišnu točku svojih intervencija mogu postići značajni uspjesi u unapređenju položaja različitih, osobito ranjivih, društvenih skupina te ujedno utjecati na smanjenje financijskih troškova povezanih s postizanjem tog cilja.

Ključne riječi: razvoj zajednice; promocija zdravlja; obitelj; djeca; mladi. 
Radovi Zavoda za znanstveni rad HAZU Varaždin; br. 30, 2019, str. 479-508

\section{SUMMARY}

\section{SOME DETERMINANTS OF COMMUNITY DEVELOPMENT AND HEALTH PROMOTION FOR FAMILIES, CHILDREN AND YOUTH}

Modern approaches to health determination have been influenced since long time ago by the notions that describe it as a state of complete physical, mental and social well-being,and not just the absence of illness. Particularly vulnerable social groups such as families, children and young people, as well as many specific categories of the population such as refugees, poor people, ethnic, sexual or racial minority groups are additionally affected in the communities in which they live by the influence exerted on them by members of that same community. As a result, approaches and models have evolved in the theory and practice of different professions dealing with population health (such as medicine, social work, psychology, etc.) within the last decades, within the paradigm of community development and health promotion. In this way, the community and the concept of health became inseparable. Community health is the ability of a community to create and successfully use resources to support the well-being and quality of life of the community. Community development refers to the process of fostering a sense of community, strengthening social ties between people, raising cohesion with the aim of achieving a harmonious, supportive, and stimulating and engaging environment for people. It builds on the development of community resources that can be found, among other things, in self-help groups, the social support system, or the development of systems that enhance citizen participation in directing and shaping health priorities. Community health promotion is a conceptual framework that emphasizes primary prevention and a community-based perspective, and can be viewed as a philosophy, process, project or outcome. Community development and community health promotion contain the fundamental belief that people can identify and solve their problems. To this end, a number of community-based work models have been developed, some of which are ideally-typed and some derived from the practice of professionals around the world. The paper presents some key determinants of the concepts of community development and health promotion, the characteristics of the contexts in which the processes of community development and health promotion take place, the specifics of particular models of work, their key values and their goals. In conclusion, it was emphasized that community development and promotion of community health are an essential aspect of contemporary health practices and policies, and that using the community as a starting point for their interventions can achieve significant success 
in promoting the position of diverse, especially vulnerable, social groups and at the same time reducing financial costs associated with achieving that goal.

Key Words: community development; health promotion; family; children; youth. 